\title{
La memoria visual de una dinastía. Pedro IV EI Ceremonioso y la retórica de las imágenes en la corona de Aragón (1336-1387)*
}

\author{
Joan Molina Figueras \\ Universitat de Girona \\ joan.molina@udg.edu
}

\section{RESUMEN}

Durante todo su reinado Pedro IV de Aragón hizo uso de todo tipo de medios de comunicación, desde crónicas y sermones hasta imágenes, con el objetivo casi obsesivo de preservar y promover la gloriosa memoria de su linaje real. Al margen del valor intrínseco de todas y cada una de estas manifestaciones, en determinadas ocasiones se llegó incluso a diseñar espacios multimedia mediante una hábil interacción de diferentes sistemas comunicativos. Así pienso que sucedió en el Salón del Tinell del Palacio Real Mayor de Barcelona y en el panteón real del monasterio de Poblet, dos escenarios donde la contemplación de amplios programas figurativos ad maiorem gloriam de la dinastía catalanoaragonesa corrió paralela a la lectura o audición de piezas literarias concebidas con el mismo objetivo. El resultado fue la creación de unos extraordinarios espacios-espectáculo de la monarquía, unos lugares con una enorme carga retórica que contribuyeron a acentuar el sentido legitimador y simbólico de los propios monumentos.

Palabras clave: Memoria dinástica, iconografía del poder, cultura visual, Pedro IV de Aragón, escultura gótica, Corona de Aragón, Palacio Real Mayor de Barcelona, Panteón del monasterio de Poblet, formas y significados.

\section{Visual memory of a dynasty. Pedro IV the Ceremonious and the rhetoric of images in The Crown of Aragon (1336-1387)}

\begin{abstract}
Throughout his reign Peter IV of Aragon made use of all kinds of media, from chronicles and sermons to pictures, with an almost obsessive goal of preserving and promoting the glorious memory of his royal descent. Apart from the intrinsic value of each and every one of these manifestations, it should be pointed out that on certain occasions they even design multimedia spaces by means of a smart interaction of different communication systems. I believe that this happened in the Saló Tinell Room of the Royal Palace of Barcelona and in the Royal Pantheon of Poblet Monastery, two scenes where the contemplation of comprehensive and figurative programmes ad gloriam maiorem of the CatalanAragonese dynasty was simultaneous at the reading or audition of literary pieces created for the same purpose. The result was the creation of extraordinary show locations of the monarchy, places charged with rhetoric that emphasized the legitimate and symbolic meaning of these monuments.
\end{abstract}

Key words: Dynastic Memory, Iconography of Power, Visual Culture, Peter IV of Aragón, Gothic sculpture, Crown of Aragon, Royal Palace of Barcelone, Royal Pantheon of Poblet Monastery, Forms and Meanings.

* Este estudio se enmarca en el proyecto de investigación “Artistas, patronos y público: Cataluña y el Mediterráneo” HAR2011/23015 financiado por el Ministerio de Ciencia e Innovación 
"A nos pertany en nostra memoria los llurs feits retenir, com foren prous e valents combatedors" 1 . El deber de recordar el valor y las gestas de quienes nos han precedido. Cuando en 1370 Pedro IV proclamaba este voto en el sermón de apertura de las Cortes de Tarragona, el culto a la historia dinástica contaba ya con una larga tradición entre los monarcas aragoneses. No en balde se había convertido, desde hacía más de un siglo, en el eje vertebrador de una amplia panoplia de medios de comunicación (crónicas, discursos, imágenes) con los que los reyes buscaron fundamentar su prestigio y autoridad ante todos sus súbditos ${ }^{2}$. El auge experimentado por la historiografía áulica y su influencia en las composiciones homiléticas para las cortes certifican, de manera patente, la voluntad de convertir las gestas de los reyes en el instrumento fundamental de la campaña de sacralización de los monarcas aragoneses desplegada a lo largo de toda la Baja Edad Media. Recordar para mitificar; recordar para proclamar la naturaleza casi sobrenatural de unos seres protegidos por la divinidad ${ }^{3}$.

A buen seguro ningún monarca mostró mayor interés por la preservación de la gloriosa memoria del linaje como Pedro IV. Dan fe de ello las crónicas que escribió e hizo escribir a sus colaboradores (desde la dedicada a su propio reinado a las que versaban sobre la historia dinástica) así como los múltiples sermones de cortes, cartas y discursos públicos en los que se rememoraban las heroicas gestas de sus antecesores ${ }^{4}$. Compilador e imitador de costumbres y usos establecidos por sus predecesores en el trono, fue el factotum de una amplia y ambiciosa operación de propaganda de la monarquía aragonesa cuyo tono retórico y grandilocuente superó todo lo realizado hasta el momento ${ }^{5}$. Su obsesión por preservar y difundir la memoria dinástica, entendida como el pilar fundamental sobre el que se asentaba dicha campaña de exaltación áulica, le impulsó incluso a ejercer un control directo sobre todos los medios y manifestaciones utilizados para lograr tan anhelado objetivo. De ahí su implicación personal en buena parte de los productos escritos (y, como veremos, también en los visuales) dedicados a su persona o a sus ancestros. Había que conjurar el olvido, como bien apuntó Gimeno Blay, quien detectó incluso esta actitud en el gesto del monarca de introducir anotaciones de su puño y letra en los documentos de cancillería y en las ordinacions de la Casa Real ${ }^{6}$. Una intervención parecida a la que también se percibe en su propia crónica, sobre la que realizó un minucioso seguimiento durante todo el proceso de redacción. $\mathrm{O}$ en los sermones de cortes, discursos solemnes y eruditos dirigidos a un gran público y, por lo tanto, con un evidente efecto propagandístico. Intervenciones, directas en ocasiones o en estrecha colaboración con sus consejeros

1 Parlaments de les Corts Catalanes, R. ALBERT y J. GASSIOT, Barcelona, 1928, p. 48.

2 S.M. CINGOLANI, La memòria dels reis. Les quatre grans cròniques, Barcelona, 2007, pp. 226-229.

3 "Lleixam aquest libre per memòria a aquells qui volran oir les gràcies que Nostre Senyor nos ha feites, e per exempli a tots los altres hòmens del món". JAIME I, Libre dels feits, cap. 1. Cit. F. SOLDEVILA, Les Quatre Grans Cròniques, BARCELONA, 1971, p. 2.

4 S.F. CAWSEY, Reialesa i propaganda. L'eloqüència reials i la Corona d'Aragó, ca. 1200-1450, Valencia, 2008, pp. 63 y 97 ss.

5 P. CORRAO, "Celebrazione dinastica e costruzione del consenso nella Corona d'Aragona", P. CAMMAROSANO (coord.), Le forme della propaganda politica nel Due e nel Trecento, Roma, 1994, pp. 133-156.

6 F.M. GIMENO BLAY, Escribir, reinar. La experiencia gráfico-textual de Pedro IV el Ceremonioso, Madrid, 2006, pp. 145-156. 
más próximos en otras, que revelan hasta qué punto Pedro IV fue consciente de la capital importancia que tenía el control de la redacción y la presentación de la historia dinástica. De un elaborado relato del pasado que, gracias a la mitificación de la memoria, habría de servir para presentarse a sí mismo y a todos sus predecesores en el trono bajo una óptica providencialista; bajo el tono mesiánico característico de aquellos que se consideran elegidos por la divinidad.

Las ceremonias y los espectáculos regios, las imágenes efímeras o perennes protagonizadas por la monarquía, fueron también unos poderosos medios de comunicación que, paralelamente al auge historiográfico y homilético, cobraron cada vez mayor relieve como soporte para la evocación y transmisión de la historia dinástica ${ }^{7}$. Sin embargo, de nuevo aquí hubo que esperar hasta el reinado de Pedro IV para que se alcanzase el momento culminante. Sin despreciar la importancia de otros períodos anteriores -en especial la época de Jaime II- creo no equivocarme al afirmar que fue entonces cuando tuvo lugar la apoteosis de la imagen del rey en la Corona de Aragón. El esplendor y profunda carga simbólica otorgada a las ceremonias de coronación y a las exequias; la perfecta codificación de la liturgia del palacio mediante las ordinacions de la Casa Real; la reconstrucción y embellecimiento de las residencias áulicas y, por supuesto, la promoción de múltiples imágenes del rey y de sus ancestros en variados escenarios y soportes señalan, vistos en su conjunto, la espectacular inflación de las representaciones visuales de la monarquía auspiciada por Pedro IV. Es por ello que no sorprende que durante este período se materializaran dos espectaculares y ambiciosas celebraciones dinásticas, ambas escultóricas: una galería genealógica para la sala mayor del Palacio Real de Barcelona y un gran panteón funerario construido en la iglesia del monasterio de Poblet. Obras realizadas bajo el patrocinio del monarca, quien para su ejecución contrató, y a veces incluso obligó a participar forzadamente, a algunos de los más destacados escultores activos en sus dominios ${ }^{8}$.

\section{El palacio, escenario del culto a la dinastía}

Entre 1340 y 1342 se fechan las primeras noticias del encargo a Aloi de Montbrai de una serie de efigies en alabastro dedicadas a los once condes y los ocho condesreyes de Barcelona 9 . Ninguna de ellas ha alcanzado nuestros días y, lo que es peor, tampoco contamos con ninguna descripción detallada de las mismas ${ }^{10}$. Por contra

7 A. SERRA, "Ab recont de grans gestes. Sobre les imatges de la història i la llegenda en la pintura gòtica de la Corona d'Aragó", Afers, 41 (2002), pp. 15-35. Desde una perspectiva más general, F. ESPAÑOL, Els escenaris del rei, Manresa, 2001.

8 J. MOLINA, "Gli artisti del re nel Trecento aragonese", Annali della Scuola Normale Superiore di Pisa, 16 (2003), pp. 193-213.

9 La regesta documental en A. RUBIÓ I LLUCH, Documents per l'història de la cultura catalana migeval, Barcelona, 1908, vol. I; J.M. MADURELL I MARIMÓN, "El Palau Reial Major de Barcelona. Recull de notícies històriques", Analecta Sacra Tarraconensia, XII (1936), pp. 491-518; y "El palacio Real Mayor de Barcelona. Nuevas notas para su historia", Analecta Sacra Tarraconensia, XIV (1937-1940), pp. 89-112.

10 Aunque en numerosas ocasiones dichos retratos se han querido imaginar con un aspecto semejante a la imagen de San Carlomagno (Gerona, Museo de la Catedral), lo cierto es que ni su ubicación ni su uso 
disponemos de varias noticias sobre el proyecto que nos informan del lento proceso de ejecución y entrega de las imágenes áulicas, que se dilató hasta inicios de los años 70. Destinadas al Palacio Real Mayor de Barcelona, también desconocemos cuál fue la primera ubicación pensada para ellas en torno a 1340; sólo en un documento fechado en 1360 se apunta que "les ymages e senyals dels reis passats d'Aragó e dels comtes de Barcelona" debían instalarse en los canecillos o capiteles de los arcos de la nueva y flamante sala mayor del palacio (Salón del Tinell), una vasta cámara de planta rectangular cubierta con arcos diafragma $(17$ x 33,5 m.) iniciada por Guillem Carbonell en torno a 1359 y concluida en 1370 (fig. 1).

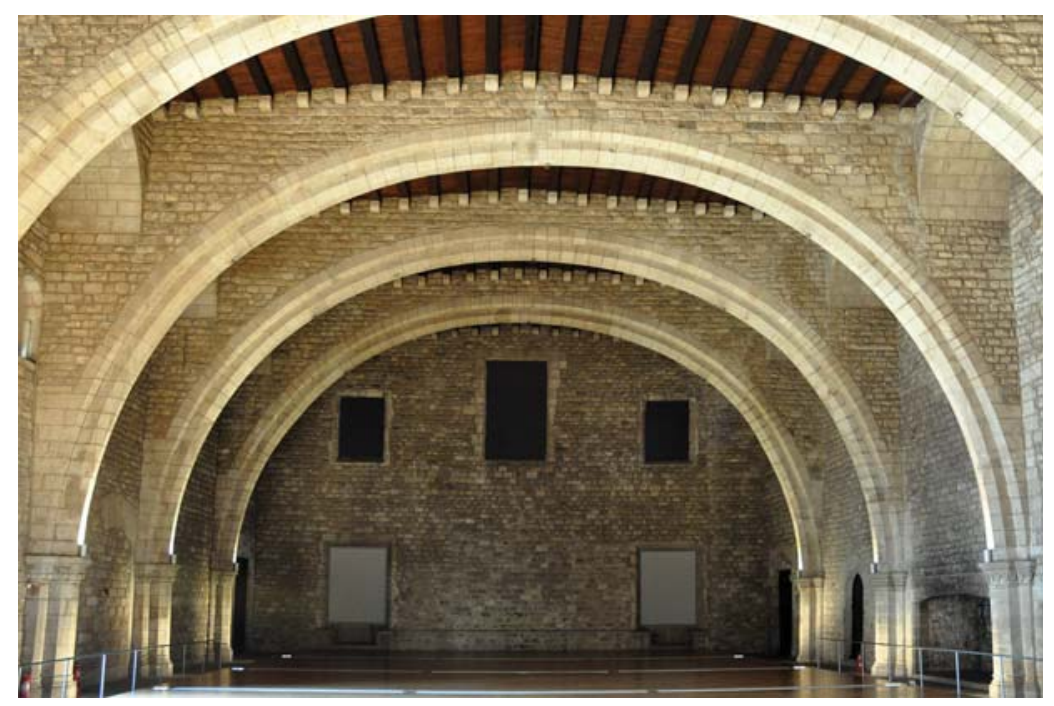

Fig. 1. Guillem Carbonell, Salón del Tinell (1359-1370). Palacio Real Mayor de Barcelona.

Hoy vacío y desnudo, el estado actual de este espacio de grandes dimensiones hace difícil imaginar cuál fue la posible distribución de las imágenes a lo largo de sus muros, establecida probablemente a partir de una ordenación cronológica y de algunos paralelismos simbólicos entre los monarcas representados, identificables gracias a la presencia de tituli y armas ${ }^{11}$. Tampoco nos es posible evocar la fuerte carga dramática y efectista, casi escenográfica, que sin lugar a dudas debía ofrecer el recinto arquitectónico con tal galería de retratos. Es bien conocido, gracias a otros conjuntos medievales, que las imágenes monumentales otorgaban un sentido teatral y fuertemente retórico a los espacios que las acogían. Por lo que respecta a los posibles modelos

sustentan un paralelo con esta relativamente pequeña estatua de culto, concebida para un ambiente y función bien diferentes.

11 J.M. MADURELL I MARIMÓN, op. cit., 1837-40, p. 93, llegó a apuntar una posible distribución más o menos simétrica de las estatuas a lo largo de los cuatro lienzos de muro. Se trata, en cualquier caso, de una hipótesis sin ningún apoyo documental. 
del proyecto, se ha hecho mención a diferentes series dinásticas recreadas en palacios hispánicos y europeos del Trescientos, desde aquéllas presentes en los alcázares de Toledo y Sevilla -en la actualidad de problemática y discutida cronología- a las talladas en la Navarra de Carlos II o en el París de Carlos V. Sin embargo, aún hoy, la hipótesis más plausible es la que plantea un vínculo con la gran sala del Palais de la Cité de París, decorada en tiempos de Felipe el Bello con una gran serie-galería dinástica de esculturas $(1313)^{12}$. A los paralelos conceptuales, técnicos e iconográficos cabría añadir otro argumento indirecto pero que se me antoja igualmente importante. Me refiero al gran conocimiento de la corte francesa y a la imitación de sus gustos y usos por parte del monarca aragonés ${ }^{13}$. "Nos cobegem e affectem molt e nos sens rahó, saber l'estament de la casa de França, e aço per lo gran deure e l'acostament que havem ab aquella", afirmaba explícitamente Pedro IV en 1356 a su embajador en la corte parisina ${ }^{14}$. El mismo rey que había contraído primeras nupcias con la princesa francesa María de Navarra; el mismo personaje que en su juventud se deleitaba con la lectura de las Grandes Chroniques de France en versión original ${ }^{15}$.

Con su explícita apología de la transmisión hereditaria de los condes-reyes, el proyecto figurativo de la galería del Salón del Tinell parece haber sido planteado desde un primer momento como una suerte de contrapartida visual de todas aquellas crónicas o discursos de cortes dedicados a celebrar una continuidad dinástica ininterrumpida. Recordemos que el modelo historiográfico fijado en la Corona catalanoaragonesa a partir de finales del siglo XIII se basaba precisamente en la historia del linaje, en la transmisión directa de la autoridad de generación en generación desde tiempos de Wifredo I (840-897) ${ }^{16}$. Con la creación de la galería escultórica se consigna otro medio de expresión, ahora visual, destinado a ilustrar enfáticamente esta continuidad dinástica, auténtica piedra angular de la legitimidad y el prestigio de la corona. Una idea que también inspiró otras obras de formato y función bien distinta a la que nos ocupa, como pueden ser la desaparecida vaina de la espada de la coronación encargada a Pere Bernés (1360) o el llamado rollo de Poblet (1409-1410), ambos ilustrados con una completa serie genealógica de los condes Barcelona y reyes de Aragón (fig. 2).

Recordemos que a mediados del siglo XIV la continuidad dinástica ya se había interrumpido o estaba a punto de hacerlo en buena parte de los grandes reinos occidentales (la Francia de los capetos había dado paso a la de los Valois; el Nápoles de los Staufen había sucumbido frente a los Anjou; Castilla estaba sumida en las tensiones que provocarían el asesinato de Pedro I y la ascensión al trono de los Trastámara).

12 U. BENNERT, "Art et propagande politique sous Philippe le Bel: le cycle des rois de France dans la Grande Salle du Palais de la Cité”, Revue de l'Art, 97 (1992), pp. 46-58. La serie escenificaba visualmente la continuidad entre las tres dinastías reales (merovingia, carolingia y capeta).

13 Algunas consideraciones al respecto en M. OLIVAR, Els tapissos francesos del rei Pere el Cerimoniós, Barcelona, 1986; F. ESPAÑOL, "Artistas y obras entre la Corona de Aragón y el Reino de Francia", C. COSMEN et alii (coord.), El intercambio artístico entre los reinos hispanos y las cortes europeas en la baja edad media, León, 2009, pp. 253-294.

14 J. TRENCHS ÒDENA, Documents de cancelleria i de mestre racional sobre cultura catalana medieval, Barcelona, 2011, p. 287, doc. 1016.

15 M. FERRER y LL. CABRÉ, "La traducció catalana (c. 1351) de les Grandes Chroniques de France", Anuario de Estudios Medievales, 42/2 (2012), pp. 653-668.

16 S. M. CINGOLANI, op. cit., 2007, p. 212. 


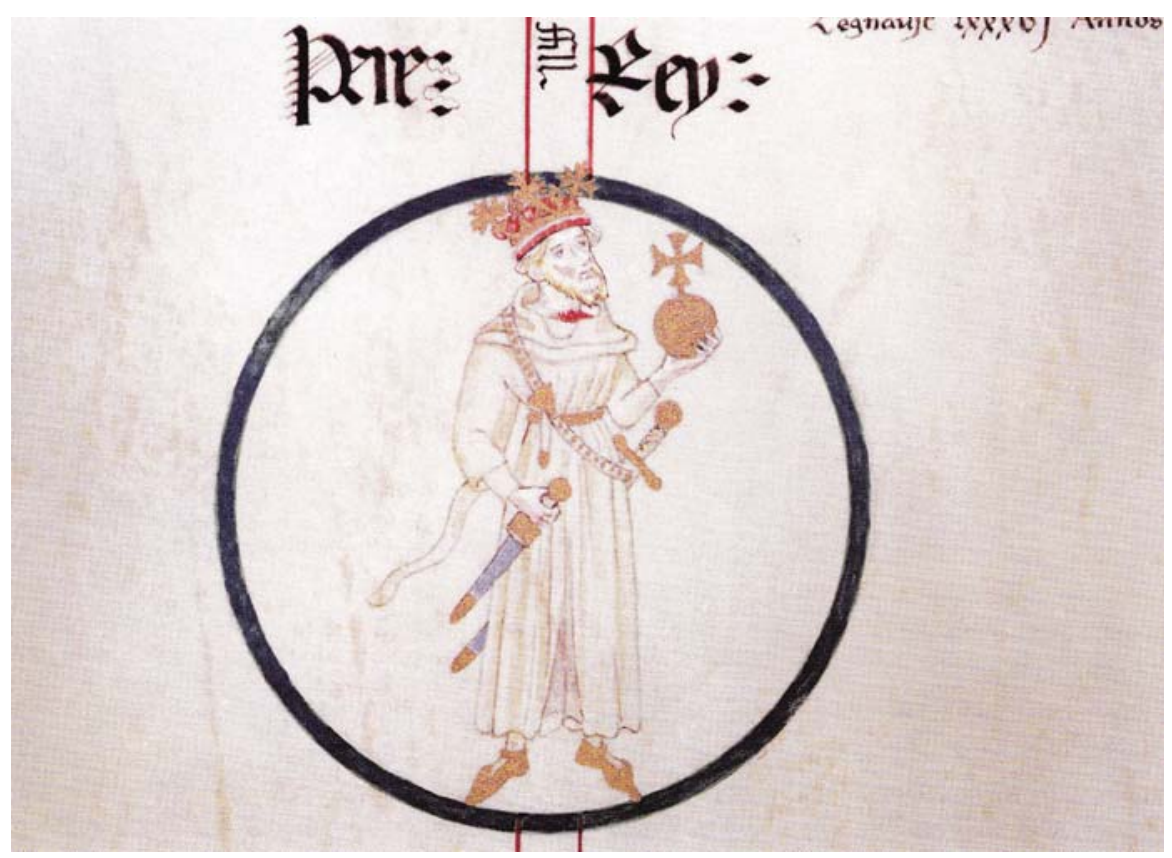

Fig. 2. Pedro IV. Rollo de Poblet. Genealogía de los Reyes de Aragón y condes de Barcelona (1409-1410) Poblet, Biblioteca del Monasterio.

Vistos en este contexto más amplio, proyectos visuales como el desplegado en el Salón del Tinell no sólo debieron ser concebidos como una solemne declaración de uno de los epítomes de la doctrina del poder sino también como una orgullosa celebración de la antigüedad del linaje y de su permanencia inalterada en el trono. Un rasgo distintivo y ostentoso frente a otras viejas dinastías, caídas ya de sus altos pedestales.

Existen pocas dudas sobre la efectividad retórica y mnemónica del locus escogido para acoger la serie de retratos escultóricos encargados a Aloi de Montbrai. Y ello por diversos motivos. Primero por la propia equivalencia simbólica del lugar en sí mismo. Desde los inicios de la Baja Edad Media el palacio, residencia pero también lugar de recepción y manifestación del monarca, se convirtió en el lugar ideal para cualquier tipo de programa dedicado a la exaltación y propaganda de la figura del rey. En este sentido, el Salón del Tinell, la sala más noble e imponente del Palacio Real Mayor de Barcelona, se antoja un ámbito perfecto para la promoción de la memoria áulica. Imaginemos, tan sólo por un momento, la vasta sala decorada con los retratos escultóricos de los miembros de la dinastía y podremos comprender al instante que nos hallamos ante una escenografía ad hoc para cualquier acto o recepción presidida por el monarca, desde una sesión de cortes a un gran banquete. En todas ellas Pedro IV se presentaría ante sus súbditos rodeado por una extraordinaria aureola dinástica al estar "acompañado" perennemente por todos los condes y reyes de su antigua prosapia. Por otra parte, en la medida que el Salón del Tinell era un lugar solemne y 
espectacular se ajustaba a algunos de los principales parámetros de las teorías mnemónicas de raíz aristotélica redescubiertas en la Baja Edad Media. En particular, a la idea de que convenía recrear las imágenes en espacios emotivos e impresionantes para así poder fijar mejor su recuerdo en la mente de los espectadores ${ }^{17}$. A imitación de los programas escultóricos de las fachadas de iglesias y catedrales, la galería de efigies reales desplegada a lo largo de los muros de la sala palatina permitió configurar un gran teatro de la memoria. Lo único es que ahora, en vez de evocar la doctrina cristiana, el objetivo era la exaltación dinástica. Un mensaje de distinta naturaleza, parecidos recursos para transmitirla.

Entre los múltiples cambios operados en la Corona de Aragón a finales del siglo XIII se cuenta la transformación de la cancillería de corte en el principal recolector de la memoria histórica, desplazando de este modo a tradicionales centros monásticos, como San Juan de la Peña o Ripoll, que hasta entonces habían desempeñado dicha función. Notarios, escribas, cancilleres, incluso el mismo monarca, participaron en la composición de los numerosos textos historiográficos que, a partir de Jaime I y sus sucesores, fueron concebidos ante todo para recordar las gestas y, al mismo tiempo, sustentar un nuevo modelo de realeza con tintes sacros y legendarios. Corte y cancillería substituyen pues a los monasterios como ámbito de producción de la memoria dinástica y con ello también se produce un mutación fundamental en el uso y divulgación de los textos. Lejos del carácter privado y monástico de piezas como las Gesta comitum Barcinonensium, un texto en latín compuesto en Ripoll a fines del siglo XII, crónicas como el Llibre dels Feits del rey Jaime I, redactada en catalán en el marco de la corte, señalan el paso hacia obras pensadas para llegar a un tipo de público mucho más amplio y diversificado ${ }^{18}$. Tanto es así que la mayor parte de las crónicas, genealogías y las obras historiográficas escritas a partir de fines del siglo XIII fueron concebidas por y para el palacio, el escenario privilegiado de su difusión. Y digo escenario porque el proceso no se concretó a través de una lectura privada en el silencio de una estancia - práctica aún minoritaria y reservada a unos pocos- sino mediante su recitación pública en espacios más o menos amplios ${ }^{19}$. La rememoración de las gestas del linaje deviene de este modo un ritual colectivo, un espectáculo en el que se busca divertir, educar y, naturalmente, hacer propaganda a unos auditorios cortesanos. A este menester se dedicaría, sin lugar a dudas, el recontador de gestes reials contratado por Pedro $\mathrm{IV}^{20}$. Un personaje, fijémonos bien, encargado de recitar en el palacio, y quién sabe si desde el mismo Salón del Tinell, las historias con tintes legendarios sobre aquellos mismos personajes retratados por Aloi de Montbrai y sus sucesores.

17 F.A. YATES, El arte de la memoria, Madrid, 2005, pp. 105-127; R. RECHT, Le croire et le voir. L'art des cathédrales (XIIe-Xve siècle), Paris, 1999, pp. 290-307.

18 S.M. CINGOLANI, op.cit., 2007, pp. 2-74.

19 Sobre la práctica de la lectura pública en las cortes bajomedievales, vid. J. COLEMAN, "Reading the evidence in Text and Image: How the History was read in Late Medieval France", E. MORRISON y A. HEDEMAN, Imagining the past in France. History in manuscript painting, 1250-1550, Los Angeles 2010, pp. 53-67.

20 S.F. CAWSEY, op. cit., 2008, pp. 134 ss. 


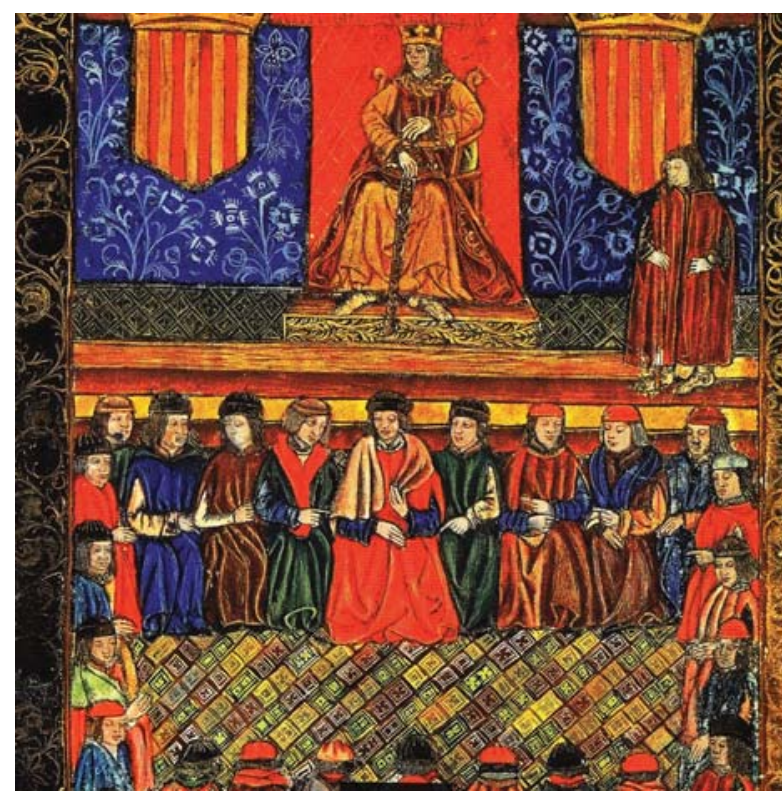

Fig. 3. El rey preside las cortes. Usatges i Constitucions de Catalunya, fol 1. ca. 1495.

Sabemos igualmente que la amplia sala que acogió el conjunto escultórico fue uno de los recintos más utilizados para la celebración de cortes durante el reinado de Pedro IV ${ }^{21}$. Dichas reuniones del monarca con todos los estamentos sociales se desarrollaban en el marco de una cuidada mise en scène: el monarca revestido con todas sus insignias de poder presidía los encuentros desde un trono situado en plano elevado, desde donde actuaba como representante de Dios en la Tierra (usurpant officia sacerdotii ${ }^{22}$ ) (fig. 3). Las sesiones se abrían con un discurso del rey, un auténtico sermón político trufado de citas bíblicas y evangélicas en el que casi invariablemente se hacía mención a la sucesión ininterrumpida en el trono del linaje aragonés y donde también había lugar para recitar las gestas de los antepasados como ilustración de su gloria y de la protección divina de que gozaron. En una de estas homilías pronunciada en Monzón (1367) Pedro IV quiso remarcar su pertenencia a una familia de personajes casi legendarios con la mención de los nombres y las grandes hazañas de todos los reyes de Aragón y condes de Barcelona. En resumen, de acuerdo con los modelos y estructura de la homilética, los monarcas aragoneses (y, naturalmente, sus acólitos cortesanos de la cancillería) construyeron unas grandilocuentes piezas retóricas en las que la memoria del linaje desempeñaba de nuevo un papel de primer orden. $\mathrm{Ni}$ que decir cabe que los programas figurativos desplegados en los escenarios donde te-

21 Once reuniones de cortes tuvieron lugar entre 1353 y 1380. Ibidem, p. 188.

22 Ibidem, p. $75 \mathrm{ss}$. 


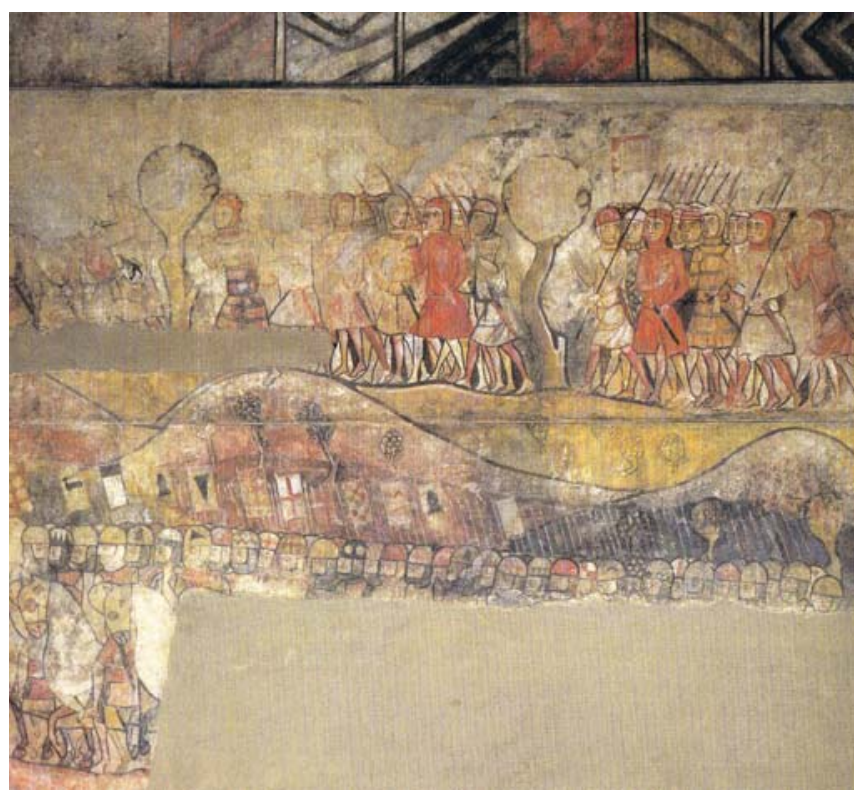

Fig. 4. Pinturas murales de la conquista de Mallorca (ca. 1285-1300) Palacio Real de Barcelona.

nían lugar las cortes podrían ayudar a proyectar en mayor o menor medida el sentido y, sobre todo, el énfasis mnemotécnico de tan significativas evocaciones históricas.

Vistas así las cosas, la inclusión de la galería dinástica en el Salón del Tinell barcelonés a partir de los años 70 del siglo XIV parece responder a la voluntad de Pedro IV y sus allegados de dar vida a lo que me atrevo a definir como un auténtico aparato multimedia. O lo que es lo mismo, con los retratos escultóricos se introdujo una pieza más en un complejo sistema de comunicación diseñado en la emblemática sala del palacio barcelonés. Pese a la distancia del tiempo aún podemos intuir el efecto emocional que debían causar las efigies de los monarcas pretéritos entre los nobles, eclesiásticos y ciudadanos que asistían a las cortes y oían al rey rememorar enfáticamente sus heroicas gestas. E igualmente, imaginar la curiosidad que las imágenes reales despertarían entre los cortesanos conocedores de los perfiles biográficos de los personajes representados gracias a las lecturas públicas de las crónicas áulicas. No creo, pues, que sea arriesgado afirmar que la suma de textos transmitidos oralmente, sermones e imágenes presentes en un momento u otro en el Salón del Tinell acabaron por conformar un entramado de discursos paralelos, todos ad maiorem gloriam del monarca. Un aparato multimedia desarrollado en el marco de la estricta liturgia cortesana establecida por las mismas ordinacions de la Casa Real que el propio Pedro IV ordenó compilar en $1343^{23}$. En este contexto parece claro que tanto las lecturas como los sermones contribuyeron a dotar de mayor eficacia retórica a las imágenes de la

23 Ordinacions de la Casa i Cort de Pere el Cerimoniós F.M. GIMENO et alii (eds.), Valencia, 2009. 
galería, ya sea aumentando su poder evocador, ya sea incrementando su capacidad para imprimir memoria entre los privilegiados espectadores (nobles, eclesiásticos, funcionarios de corte...). En resumen, que la galería real aportó un elemento decisivo para la conversión del Salón del Tinell en algo semejante a un escenográfico palimpsesto áulico.

Llegados a este punto cabe peguntarse si la concepción de un gran programa de exaltación dinástica en el Salón del Tinell diseñado entre aproximadamente 1340 y 1370 implicó una cancelación voluntaria y consciente de las pinturas murales que desde finales siglo XIII decoraban la cámara -posiblemente sala del Trono o de recepciones- sobre la que Pedro IV ordenó levantar la gran sala que nos ocupa ${ }^{24}$. Afortunadamente algunos fragmentos de estas viejas pinturas han llegado hasta nuestros días merced a que quedaron cegadas por un muro intermedio levantado durante la campaña de construcción del nuevo Salón del Tinell, momento en el que desapareció la mayor parte del ciclo figurativo (fig. 4). A partir de estos retazos conservados se ha podido conjeturar que el conjunto pictórico debía evocar la campaña de conquista de Mallorca (1229), una gesta militar emprendida en tiempos de Jaime I ampliamente recordada en las crónicas áulicas y también traducida visualmente en otros ciclos figurativos, como el bien conocido del palacio Caldes - conservado en el MNAC.

La iconografía de los restos pictóricos del Palacio Real Mayor -actualmente adosados a los muros del Salón del Tinell trecentista (fig. 5)- presenta a un gran ejército en marcha:

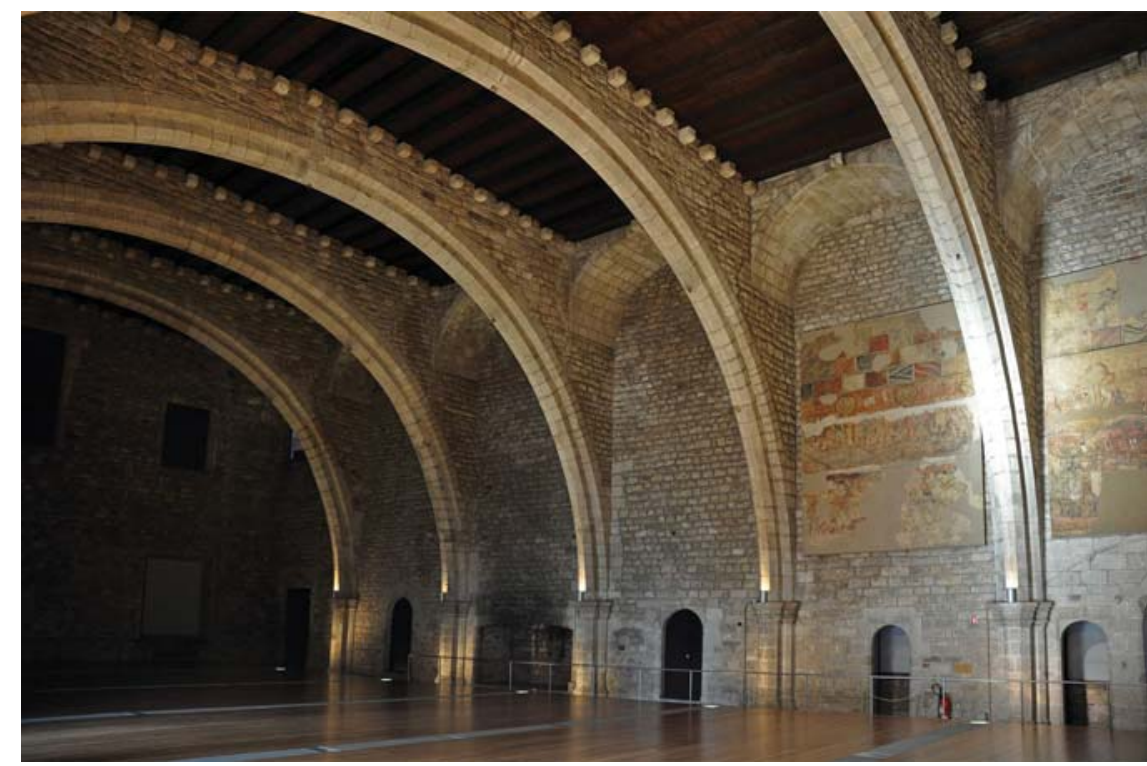

Fig. 5. Guillem Carbonell, Salón del Tinell (1359-1370). Vista actual con los restos de las pinturas murales.

24 A.M. BLASCO, Les pintures murals del Palau Reial Major de Barcelona, Barcelona, 1993. 
el avance a campo abierto de varias decenas de caballeros, ballesteros e infantes recreados a lo largo de dos amplias franjas horizontales superpuestas. Tan sólo un fragmento rompe dicho esquema compositivo y, aunque muy deteriorado, en él parece intuirse una escena de batalla entre efectivos del ejército cristiano y sarracenos. Más allá de la discusión casi bizantina - por la falta de atributos claros ${ }^{25}$ - sobre la posible identificación de uno de los caballeros representados con Jaime I, lo cierto es que con toda seguridad el monarca aparecería efigiado en el ciclo militar original. Así se desprende tanto del lugar para el que fueron concebidas las pinturas como, sobre todo, de la vinculación personal del rey con la conquista, publicitada desde un primer momento en los medios aristocráticos mediante toda la propaganda oficial en forma de crónicas y otros relatos de carácter historiográfico.

En cualquier caso no deja de resultar significativo el protagonismo que se concede en el ciclo palatino a los miembros de la nobleza; a la magnificación visual de los diferentes linajes que participaron en la conquista de la isla. Buena prueba de ello es el énfasis otorgado a la heráldica -presente en enseñas, escudos, protecciones caballos y, especialmente, cascos de los caballeros ${ }^{26}$-, que aquí parecen desempeñar no sólo un rol identificativo sino también declarativo del destacado papel que tuvieron los nobles en la campaña de conquista de la isla (fig. 6).

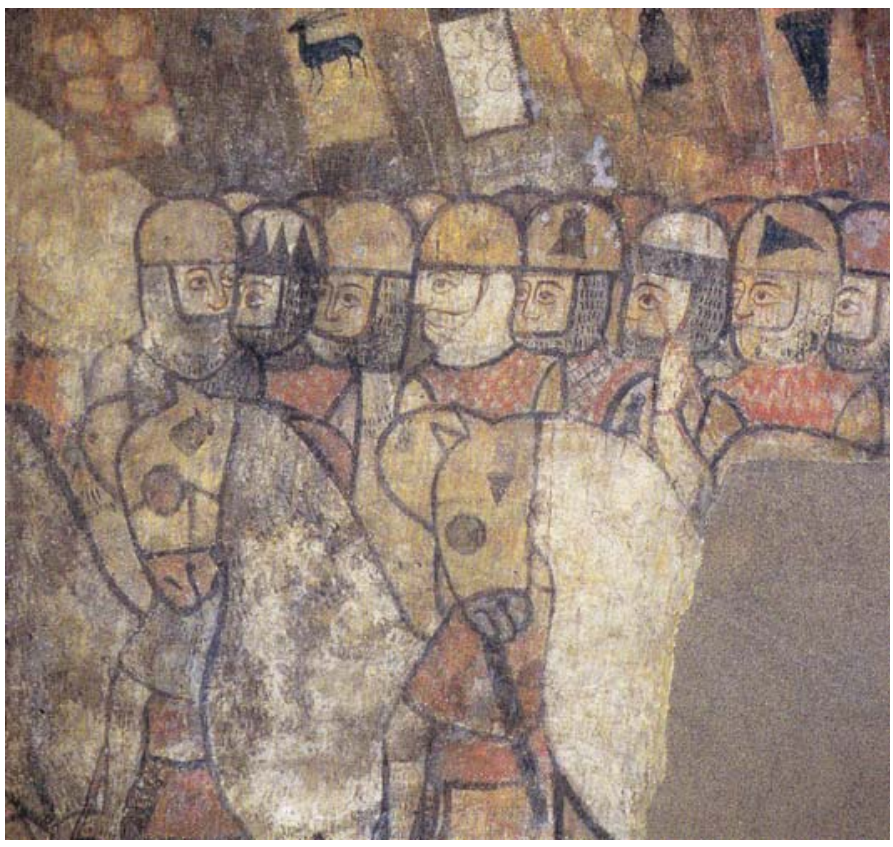

Fig. 6. Pinturas murales de la conquista de Mallorca (ca. 1285-1300). Palacio Real de Barcelona.

25 M. SERRANO, Jaime I El Conquistador. Imágenes medievales de un reinado, Zaragoza, 2008, pp. 189-191.

26 Para su identificación y lectura, vid. A.M. BLASCO, op. cit., 1993, pp. 57-58. 
Así, frente al tono de gesta nacional presidida por el monarca que se desprende de algunas crónicas oficiales, como aquella compuesta por Desclot, las pinturas palatinas parecen evocar más bien la historia de una aventura feudal. Una particularidad que se hace todavía más patente en las ya mencionadas pinturas de palacio Caldes, una obra coetánea a la del palacio real ya que fueron realizadas ca. 1285-129027, es decir, más de medio siglo después de los hechos que narran y en un contexto de apoteosis historiográfica y figurativa del acontecimiento (fig. 7). En ellas también se detecta un especial interés en dejar constancia de la importante contribución de los nobles a la gesta bélica, ya sea a través de la rememoración de los señores disidentes con la estrategia del rey (Hugo IV Ampurias y Pero Maça) o, sobre todo, mediante la evocación de la heroica muerte en el campo de batalla de los Montcada, auténticos mártires de una guerra santa. El relieve concedido a estos personajes contrasta con el otorgado a Jaime I, al que vemos presidir un consejo de guerra con otros nobles aliados y cuya posición en el conjunto del ciclo se asemeja más a la de un primus inter pares que a la de un monarca autoritario. Una versión figurativa de los hechos alejada del tono de mitificación áulica que caracteriza los relatos construidos por la historiografía oficial.

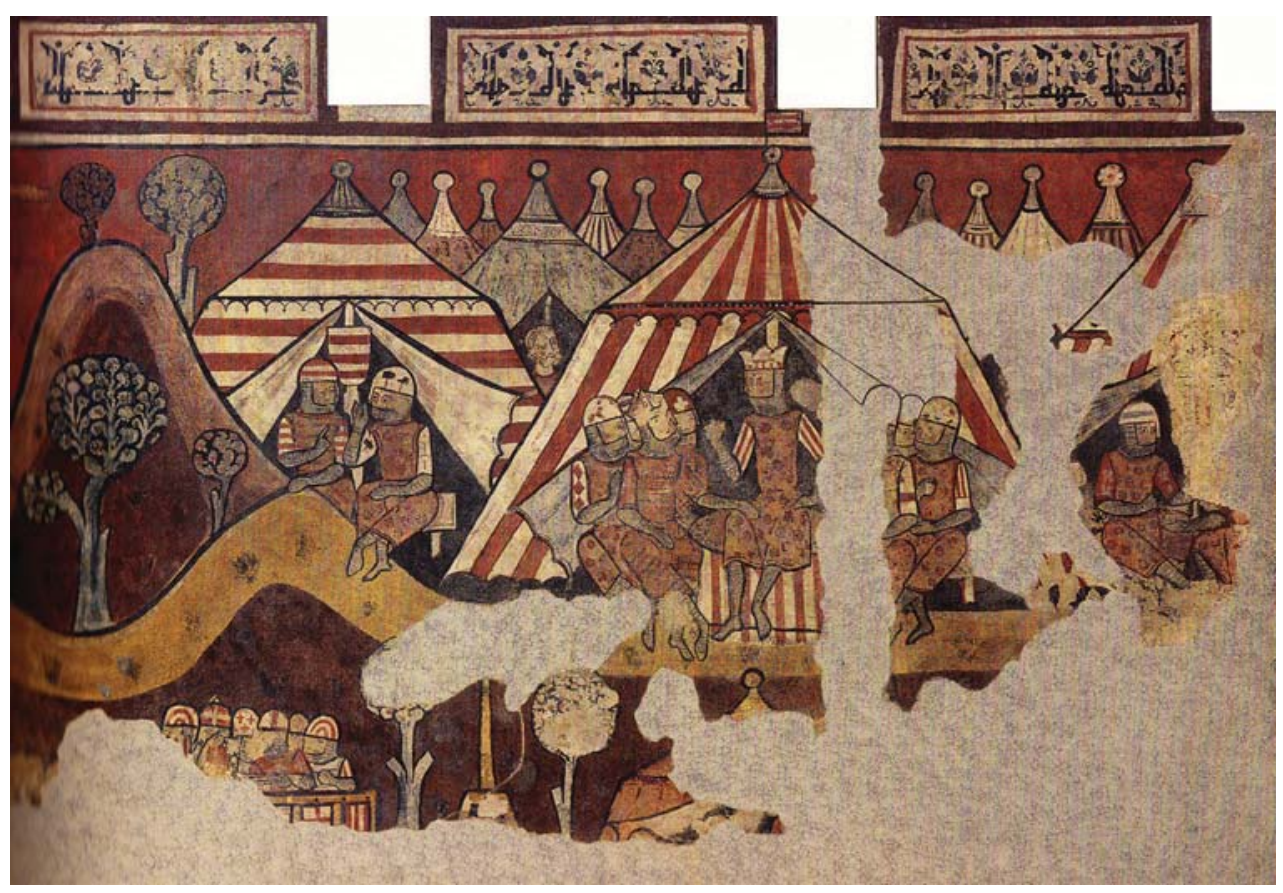

Fig. 7. Pinturas murales de la conquista de Mallorca (ca. 1285-1290). Procedentes del antiguo Palacio Caldes. Barcelona, MNAC.

27 Sobre las pinturas del Palacio Caldes, J. AINAUD, Pintures del segle XIII al carrer de Montcada de Barcelona, Barcelona, 1969; A. SERRA, op. cit., 2002, pp. 18-19; y M. SERRANO, op.cit., 2008, pp. 170-185. 
En la adopción de un determinado tipo de discurso, digamos que poco glorificador del monarca, quizás podemos hallar la razón que explique la, en principio sorprendente, decisión de Pedro IV y los constructores del nuevo Salón del Tinell de suprimir las antiguas pinturas de la conquista de Mallorca. A primera vista parece que el ciclo iconográfico debería haber sido considerado por el monarca como un elemento fetiche, una auténtica reliquia de la memoria áulica, puesto que narraba la gesta de su amado y admirado Jaime I, al que desde joven tomó como modelo. Unas imágenes que le ofrecerían, incluso, la posibilidad de presentarse como un émulo de su antepasado, ya que en 1343 él mismo dirigió una nueva conquista de la isla, esta vez ante las fuerzas de Jaime III ${ }^{28}$. Todo apunta, pues, a que en principio a Pedro IV no le incomodaría disponer de un recuerdo de las gestas de Jaime I en su nueva e impresionante sala de recepciones, si no todo lo contrario. Sin embargo es muy posible que le atrajera muy poco la manera en que era contado este trascendental capítulo de la historia de su linaje, que le desagradara una versión figurativa de los acontecimientos en la que se concedía un destacado protagonismo a la nobleza. Son bien conocidos los numerosos y graves conflictos que desde los inicios de su reinado Pedro IV mantuvo con los miembros del estamento militar, especialmente en Aragón y Valencia. Recordemos, además, que buena parte de la historiografía oficial -empezando por el propio Llibre dels Feits de Jaime I- fue concebida como un instrumento propagandístico para contrarrestar el papel de la nobleza ${ }^{29}$. No parece, pues, que existieran demasiados motivos para conservar unas pinturas palatinas en las que se otorgaba relieve y prestigio histórico a estos incómodos y rebeldes súbditos del monarca. Unas viejas pinturas que, además, estaban desprovistas de toda la iconografía mitificadora de la figura de Jaime I diseñada en la época de Pedro IV, aquélla que conllevó la incorporación de elementos sacralizadores a la figura del monarca conquistador como la figura de San Jorge o el símbolo del dragón alado ${ }^{30}$. Desde esta perspectiva la supresión del ciclo de la conquista de Mallorca representado en el Palacio Real de Barcelona se antoja una suerte de ejercicio de damnatio memoriae resultado de la voluntad expresa de cancelar una imagen del pasado que a mediados del siglo XIV sería considerada anacrónica $y$, sobre todo, poco favorable para el monarca. En su lugar, ya lo hemos visto, Pedro IV promovió una monumental reforma arquitectónica concebida para proyectar una memoria grandilocuente y retórica. Un nuevo espacio que contribuyera a la sacralización del rey gracias a la intersección entre las esculturas de la galería dinástica y la exaltación del linaje contenida en discursos y crónicas.

28 Incluso sabemos que durante la expedición le acompañó un pintor, Ramón Pagés (J. TRENCHS, op. cit., 2011, p. 213, doc. 725), quien lo más probable es que estuviera encargado de decorar escudos y otros elementos heráldicos más que dedicado a esbozar el esquema de una crónica visual de la aventura militar.

29 S.M. CINGOLANI, op. cit., 2007, pp. 64-68.

30 Así se observa en el retablo del Centenar de la Ploma. A. SERRA, op. cit., 2002, pp. 32-33; M. MIQUEL, "El gótico internacional en la ciudad de Valencia. El retablo de san Jorge del Centenar de la Ploma", Goya, 336 (2011), pp. 191-213; J. MOLINA, "Pedro IV y la mitificación visual de la monarquía”, en prensa. 


\section{Poblet y el espectáculo de la memoria}

Como ya hemos apuntado, a lo largo del siglo XIII el palacio substituyó al monasterio como ámbito preferente para la construcción, narración e ilustración de las gestas de la monarquía aragonesa; se convirtió en el escenario privilegiado de la proyección retórica de la historia del linaje real ${ }^{31}$. La realidad de este cambio es inapelable. Sin embargo, que los monasterios estrechamente vinculados a la monarquía dejaran de ser los principales centros productores de textos historiográficos no supuso que quedaran postergados a un ámbito marginal en este terreno. Su arraigado prestigio, su carácter sacro y la seguridad que ofrecían sus bibliotecas los seguían haciendo especialmente adecuados para desempeñar un importante papel: el de reserva de la memoria áulica. Un rol en principio pasivo, no activo, pero igualmente trascendental si tenemos en cuenta la imperiosa necesidad de preservar y cuidar los manuscritos que contenían los textos producidos en la cancillería real y en otros ámbitos cortesanos. De ello fue perfectamente consciente Pedro IV, quien en 1366 decidió enviar al monasterio de Ripoll un bello códice de la Crónicas de los Reyes de Aragón y condes de Barcelona (hoy en la Biblioteca Universitaria de Salamanca, ms. 2664) con la implícita indicación de que "volem que en lo dit monestir sia haguda memoria"32. Una situación parecida se observa en el campo de las imágenes. Sólo unos años antes, en 1358, el mismo monarca se dirigía al abad rivipullense para solicitarle un minucioso informe sobre en "quina manera e forma son figurats e pintats tots los comtes de Barchinona" que estaban allí enterrados y en el que se habían de incluir detalles sobre los vestidos de armas y los rasgos fisionómicos ${ }^{33}$. Una noticia que confirma hasta qué punto el antiguo monasterio condal fue contemplado por Pedro IV como un magnífico depósito sagrado de los textos e imágenes de sus antepasados.

Cierto es que en determinados cenobios nuestro monarca no sólo buscó la preservación de la memoria del linaje, sino también concretar nuevas formas para su retórica exaltación ante selectos auditorios. Así ocurrió en el monasterio cisterciense de Poblet, escenario del proyecto figurativo más ambicioso de Pedro IV. Me refiero, claro está, al panteón real que promovió para que contuviera sus restos junto a los de una amplia pléyade de familiares (coetáneos, antepasados y sucesores) ${ }^{34}$ (fig. 8). El conjunto funerario sufrió numerosas destrucciones y mutilaciones a lo largo de la primera mitad del XIX y fue objeto de una concienzuda restauración dirigida por

31 S.M. CINGOLANI, "Del monasterio a la cancillería. Construcción y propagación de la memoria dinástica en la Corona de Aragón”, P. MARTÍNEZ SOPENA y A. RODRÍGUEZ, (eds.), La construcción medieval de la memoria regia, Valencia, 2011, pp. 365-386.

32 A. RUBIÓ I LLUCH, op. cit., 1908, doc. CCXVI, pp. 212. Significativamente, de esta crónica el rey también pagó una copia con destino al Archivo Real. Ibidem, doc. CCXXV, p. 218.

33 Ibidem, doc. CLXXXIV, pp. 185-186.

34 Sobre el panteón de Poblet (historia, documentación, destrucción parcial, restauración), vid. E. TODA, Panteones reales de Poblet, Tarragona, 1935; F.M. MARÉS, Las tumbas reales de los monarcas de Cataluña y Aragón en el monasterio de Santa María de Poblet, Barcelona, 1953; R. DEL ARCO, Sepulcros de la Casa Real de Aragón, Madrid, 1945; A. ALTISENT, Història de Poblet, Abadia de Poblet, 1974; J. BRACONS, "Operibus monumentorum que fieri facere ordinamus: l'escultura al servei de Pere el Cerimoniós", Pere el ceremoniós i la seva época, Barcelona, 1989, pp. 223-226; y M.R. MANOTE y M.R. TERÉS, "El panteó reial de Poblet", L'art gòtic a Catalunya. Escultura I. La configuració de l'estil, Barcelona, 2007, pp. 183-198. 


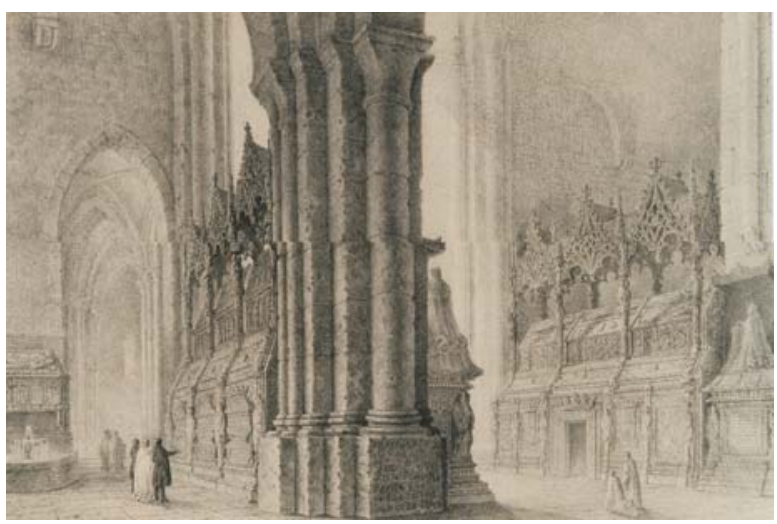

Fig. 8. Panteón Real de Poblet. Iglesia del monasterio. Grabado de F. X. Parcerisa, Recuerdos y bellezas de España, 1839.

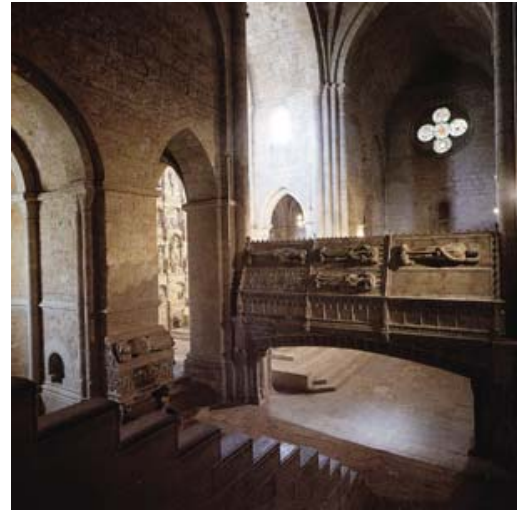

Fig. 9. Panteón Real de Poblet. Iglesia del monasterio. Vista de uno de los arcos escarzanos tras la restauración de Frederic Marés de los años 40 del siglo XX.

Frederic Marés tras la Guerra Civil. Uno de los objetivos de dicha intervención fue el intento de repristinar el monumento de acuerdo con el diseño arquitectónico que, según la documentación exhumada, debió tener a inicios del siglo XV. Ello, entre otras cosas, supuso la recuperación de la imagen de los sepulcros sobre dos arcos rebajados y la consiguiente eliminación de las tumbas de los Aragón-Cardona practicadas en la zona inferior durante el siglo XVII (fig. 9).

Como sucede con el resto de panteones levantados por los monarcas bajomedievales, se trata de un monumento concebido para ganar la salvación de las almas que en la misma medida que satisface unas expectativas soteriológicas también responde a un explícito deseo de exaltación del linaje y de su legitimidad histórica, en suma, a la glorificación de la monarquía. Cabe recordar que Pedro IV siempre demostró una especial atención hacia los sepulcros de sus predecesores, comenzando por aquellos de sus padres (1337-1338) y acabando por los de antepasados remotos como Ennec, rey de Pamplona, o el conde Ramon Berenguer II y la condesa Ermessenda (1385). De hecho, la creación, renovación o restauración de los monumentos funerarios de los ancestros constituye un verdadero topos del reinado de Pedro IV, convencido como estaba de que ésta era una de las formas más adecuadas para preservar la memoria dinástica.

Ahora bien, en ningún lugar todo ello se manifiesta de manera más clara y rotunda, con mayor madurez y espectacularidad, que en el panteón de Poblet, auténtico canto en piedra a la continuidad y legitimidad del linaje así como celebración de algunos de sus más destacados representantes. En la Península, en la misma Corona de Aragón, existen numerosos panteones bajomedievales pero pocos, muy pocos, pueden compararse en ambición y resultados al populetano. En este sentido su sorprendente y magnífico diseño se ajusta perfectamente a la voluntad de ofrecer una imagen cohe- 
rente de continuidad. Para lograr este objetivo poco importó ajustarse plenamente a la realidad histórica, por ejemplo a la hora de representar las efigies de los antepasados. Es bien conocido que una de las figuras yacentes realizadas para la tumba doble de Jaime I acabó siendo instalada en el sepulcro de Alfonso II $^{35}$. Una prueba evidente de que las imágenes de los monarcas integrados en el panteón eran puramente representativas y que serían identificadas por sus símbolos heráldicos y, sobre todo, por los epitafios que las acompañaban. Más allá de cualquier atisbo de realismo figurativo (en muchos casos imposible por la desaparición tiempo atrás de los monarcas efigiados) aquello que interesó a Pedro IV y a sus colaboradores fue concretar una coherente y espectacular imagen de todo el conjunto dinástico.

En la elección del cenobio tarraconense fundado por Ramón Berenguer IV jugó un destacado papel tanto su situación geoestratégica como sus buenas comunicaciones con los tres grandes territorios (Aragón, Cataluña y Valencia) que integraban la confederación. Algo de lo que ya no podían hacer gala los viejos monasterios de Ripoll y Sigena, por entonces absolutamente periféricos. Sin embargo, aún teniendo en cuenta los elementos de orden estratégico, uno de los motivos fundamentales que debieron inclinar a Pedro IV a escoger Poblet (y no Santes Creus, por ejemplo) fue la presencia de los sepulcros de Alfonso II y Jaime I en la iglesia monástica, probablemente "in loco per quem vadant ad altare transeuntes" ${ }^{36}$. No en balde se trataba de dos personajes claves en la historia dinástica y política de la Corona de Aragón. Alfonso, hijo de Ramón Berenguer IV de Barcelona y Petronila de Aragón, había sido el primer monarca de toda la Corona por nacimiento. Por su parte, Jaime I, gracias a las conquistas de Mallorca y Valencia, se había convertido en el artífice del imperio mediterráneo y, por ende, en la figura tótem del linaje. Tales rasgos biográficos ofrecerían un indudable atractivo a Pedro IV, obsesionado como estuvo durante toda su vida por la historia familiar, por preservar y magnificar el recuerdo de los principales hitos y personajes de su linaje. En este sentido su decisión de construir en Poblet un gran panteón debe interpretarse, ante todo, como un solemne homenaje a sus dos insignes predecesores. En cualquier caso lejos de limitarse a emular unas acciones pretéritas se propuso ir más allá de todo lo realizado hasta el momento. Como ha apuntado Cingolani, la idea de "imitar para superar" constituye uno de los referentes indispensables para interpretar el sentido de buena parte de las acciones políticas y personales de Pedro IV ${ }^{37}$. De acuerdo con esta divisa, ya establecida en tiempos de Jaime I, el deseo de conocer y venerar la historia familiar debía servir para emular y, si era posible, superar los modelos establecidos por los ancestros. A la vista del monumental panteón de Poblet queda claro que Pedro IV lo logró ampliamente. Con su gesto el monasterio cisterciense se convirtió en uno de los epicentros simbólicos de la monarquía aragonesa, en una auténtica capital de la memoria dinástica.

\footnotetext{
35 "que aquella ymage del dit rey Jacme, lo qual lo dit maestre (Cascalls) havia ja feta (...) devia posar en una part del vas del senyor rey n'Amfos". F.M. MARÉS, op. cit., 1953, doc. 35, pp. 183-185.

36 A. UDINA, Els testaments dels comtes de Barcelona i el reis de la Corona d'Aragó. De Guifré Borrell a Joan II, Barcelona, 2001, doc. 19-21, pp. 137-144.

37 S.M. CINGOLANI, op. cit., 2011, pp. 377-378.
} 
Lejos de tratarse de un proyecto perfectamente planificado desde su inicio el conjunto funerario fue concebido a la manera de un work in progress. Desde 1340, fecha de la primera noticia documentada -quizás no casualmente la misma en la que se empezó la galería dinástica del Palacio Real de Barcelona- hasta la muerte del monarca en 1387 se tomaron múltiples decisiones que ilustran cambios y modificaciones propios de una obra abierta a innovaciones tanto en el concepto como en el diseño ${ }^{38}$. De hecho, inicialmente el rey sólo encargó su tumba de piedra para que fuera colocada a nivel de pavimento en el crucero, en un lugar próximo a los sepulcros de Alfonso - un caja de madera forrada con un rica tela-y Jaime I - un cenotafio de piedra sobre ménsulas y sin decoración escultórica. A partir de ese momento las noticias se suceden. La mayoría de ellas las protagoniza el propio monarca quien, de manera muy personal y directa, dictó todo tipo de cuestiones técnicas y decorativas a los diferentes escultores que se fueron sucediendo en la dirección técnica de la obra (Pere de Guines, Aloi de Montbrai, Jaume Cascalls, Jordi de Déu). De este modo fue él mismo quien, a lo largo de cuarenta y siete años, no sólo tomó la decisión de ampliar progresivamente la nómina de tumbas, $\mathrm{y}$ por tanto ampliar el conjunto funerario, sino también el responsable directo de múltiples indicaciones que afectaban directamente al diseño de los sepulcros y la arquitectura del panteón: desde la adquisición de alabastro de Beuda como material, hasta los perfiles iconográficos que habían de caracterizar a los yacentes; desde la reivindicación de una mayor expresividad de las figuras de los plorantes, hasta la demanda de una decoración de los sepulcros con vidrios esmaltados; desde la construcción de dos grandes arcos escarzanos entre los pilares del crucero como soporte del panteón, hasta la ejecución de escudos, yelmos, epitafios y grandes baldaquinos de madera pintada para culminar toda la obra. Con la adopción de estas medidas Pedro IV, convertido en auténtica alma mater del proyecto, impulsó y dirigió un grandioso monumento con el declarado propósito de reunir a algunos de sus más insignes ancestros y a los futuros reyes. De hecho, en 1377 ordenó que los monarcas que le sucedieran no pudieran ser jurados por los vasallos y súbditos si previamente no expresaban su compromiso de ser enterrados en Poblet ${ }^{39}$. Junto a todos ellos pretendía presentarse ante el Altísimo al final de los tiempos ("per ço que ensems resucitem ab los dits reys nostres predecessors al dia del Juhi"), en un explícito testimonio de la creencia en un destino soteriológico común de signo dinástico y a la convicción en el efecto salvífico de las oraciones de los monjes cistercienses. Pero si en algo destacan sobremanera los documentos sobre el largo proceso de construcción es en desvelar la personalidad de un monarca tenaz y minucioso, atento e incluso diría que obsesionado por encontrar la solución adecuada a cada cuestión técnica o decorativa planteada y, sobre todo, capaz de sobrellevar todas las dificultades financieras (y cabe recordar que fueron muchas) con tal de materializar un conjunto funerario excepcional y único: un panteón que fuera más allá de todo lo

38 Para el largo proceso de construcción del conjunto funerario vid. F.M. MARÉS, op. cit, 1953. -que cuenta con el mayor acopio documental de la obra- y A. ALTISENT, op. cit., 1974, pp. 262-296.

39 P. BOFARULL I MASCARÓ, Colección de documentos inéditos del Archivo General de la Corona de Aragón, Vol. XXVII, Barcelona, 1864, pp. 183-187. 


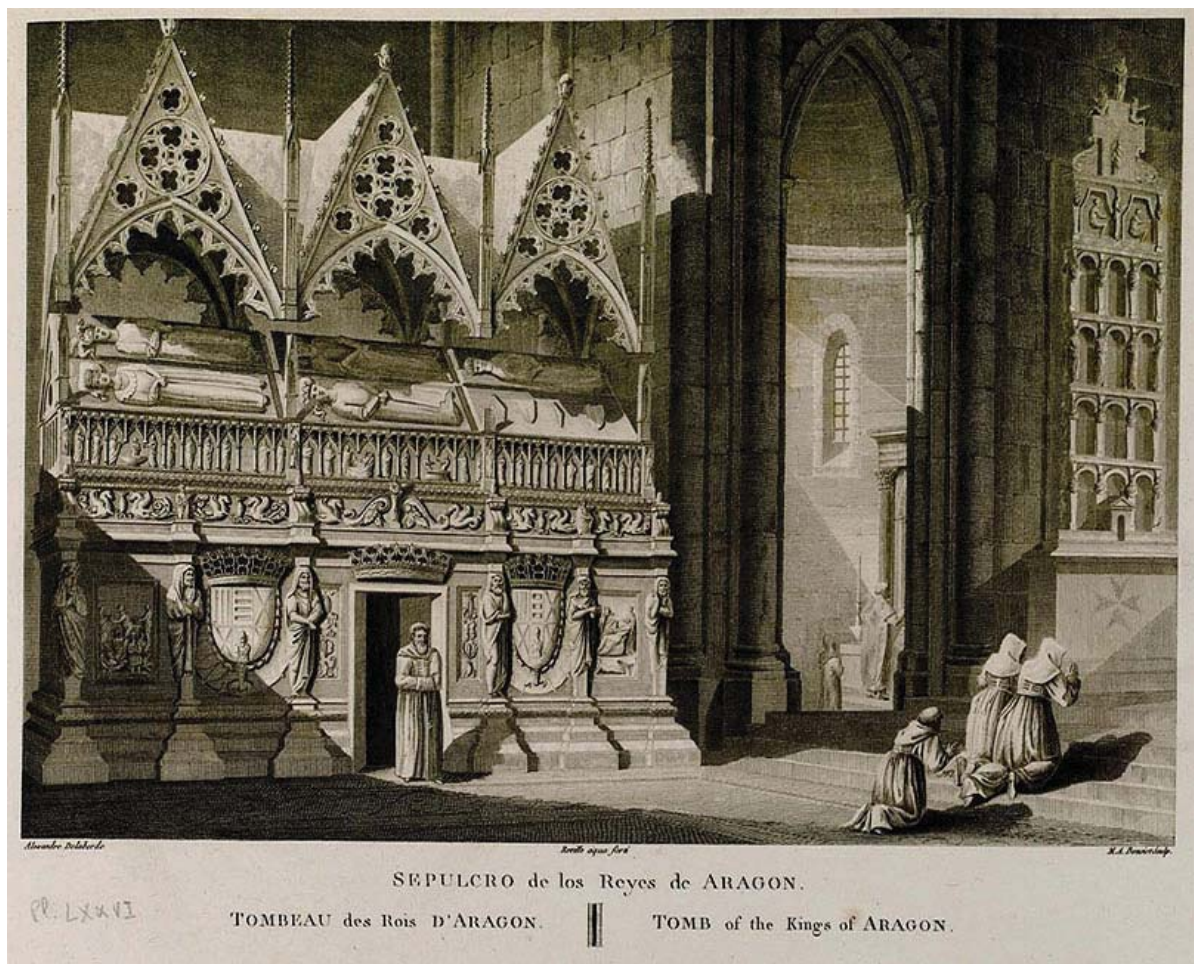

Fig. 10. Panteón Real de Poblet. Iglesia del monasterio. Grabado de Alexandre Laborde, Voyage pittoresque et historique en Espagne, 1806.

visto en este terreno hasta entonces en la Corona de Aragón, desde Ripoll y Sigena hasta Santes Creus (fig. 10).

Sin lugar a dudas uno de los mayores aciertos del proyecto fue el diseño durante los años 60 de dos enormes arcos escarzanos entre los pilares del crucero para sostener los sepulcros (fig. 9). De acuerdo con una cuidada y simbólica organización de corte dinástico, los restos de Alfonso II y Jaime I dispuestos en tumbas dobles -seguido de los de Pedro IV- encabezaban cada uno de estos elementos arquitectónicos. Les seguirían los dedicados a las esposas de Pedro IV y sus sucesores en el trono. A partir de este esquema compositivo se representaron las imágenes de los yacentes en las cubiertas y todo un amplio repertorio de iconografía funeraria en las caras exteriores (escenas exequias, plorantes, caballeros con armas a la funerala) recreado sobre brillantes fondos de vidrio esmaltado. En resumen una solución tan innovadora como espectacular. Especialmente porque los grandes arcos, al margen de facilitar la circulación de los monjes cistercienses por la zona del crucero ${ }^{40}$, posibilitaron elevar

40 X. DECTOT, Les tombeaux des familles royales de la péninsule ibérique au Moyen Age, Turnhout, 2009 , p. 211. 


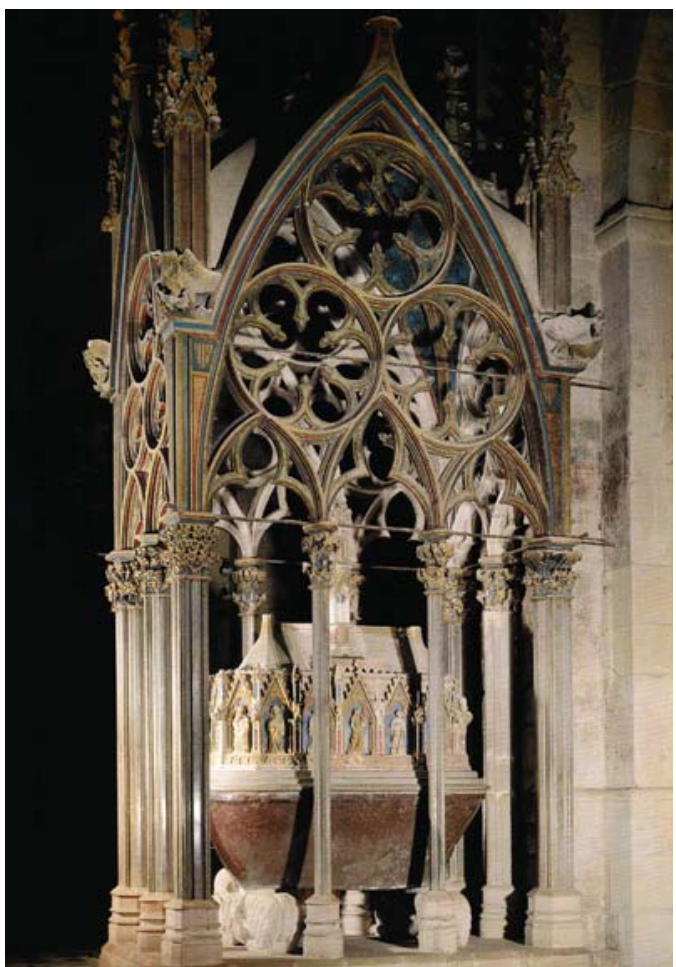

Fig. 11. Maestro Bartomeu, Guillem d'Orenga y Andreu de la Torre, Sepulcro de Pedro III. Santes Creus, iglesia del monasterio (ca. 1291-1307).

un gran número de tumbas y colocar los cuerpos de los monarcas en alto. Se rompía de este modo con una larga tradición, mantenida en el caso de los sepulcros originales de Alfonso II y Jaime I, de situar los restos a nivel del pavimento. Y se hacía de manera absolutamente consciente, como se deduce de las precisas indicaciones realizadas por Pedro IV sobre la forma y altura de los arcos. Es posible que ello tuviera que ver con fórmulas de sacralización de los sepulcros áulicos, generadas durante la segunda mitad del siglo XIII a partir de la difusión del dogma de la transubstanciación, y de la elevación del Corpus Christi durante el ritual eucarístico ${ }^{41}$. En cualquier caso, y al margen de cualquier elaborada hipótesis, lo cierto es que la sola disposición "aérea" de los insignes restos de la dinastía aragonesa, suspendidos entre el cielo y la tierra en medio del crucero, concedió por ella misma un alto valor sacralizador y simbólico a todo el monumento. ¿Qué mejor solución que ésta para evocar la memoria de un monarca que se presentó, a sí mismo y a todos sus predecesores, como el representante de una monarquía sagrada, como un intermediario entre Dios y los hombres?

41 J.C. RUIZ SOUZA, “Alfonso X y el triunfo de la visualización del poder”, Alcanate, VIII (2012-2013), pp. 219-258. 
El indudable carácter escenográfico de este diseño quedó acentuado aún más si cabe tras la incorporación, entre 1380 y 1386, de dos grandes baldaquinos de madera tallados por Bernat Teixidor. Dichas estructuras, pintadas en su interior con un brillante fondo azul punteado con estrellas doradas, se instalaron encima de los arcos para así ofrecer una solemne cobertura a las tumbas. Da la impresión que al tomar esta decisión Pedro IV o alguno de sus colaboradores pudo haberse inspirado en el panteón de Santes Creus, lugar donde ya se había concretado una presentación conjunta de sepulcro y baldaquino tanto en la tumba de Pedro III como en la de Jaime II (fig. 11).

Ocurre, en cualquier caso, que la solución adoptada en Poblet supuso un paso adelante: efectivamente, en la medida que el diseño arquitectónico del monumento se hace más complejo gracias a la combinación triple de arcos, sepulcros y baldaquinos también aumenta la tensión dialéctica entre el propio panteón y la arquitectura del templo que lo acoge. Imitar para superar. Un precepto que también sirvió para concebir las imágenes de los yacentes. Al igual que sucede con las efigies de Jaime II y Blanca de Anjou representadas en Santes Creus, en Poblet las figuras de los monarcas son recreadas sobre cubiertas inclinadas, circunstancia que permite que las imágenes se dirijan al espectador en lugar de mirar hacia arriba como sucede en la mayoría de sepulcros medievales. Ello da lugar a una composición fuertemente dramática. Y es que las imágenes, pese a estar emplazadas en lo alto, no son entes autónomos sino esculturas que interactúan con el espectador, efigies pensadas para ser contempladas. Se trataba, a la vista de todo ello, de proyectar el panteón como un espectáculo, como un gran aparato iconográfico pensado adrede para ser visto y admirado por un público ${ }^{42}$. Una propuesta que el conjunto funerario de Poblet, por su monumentalidad y sus múltiples imágenes, desarrolló hasta un nivel e intensidad desconocido hasta entonces en la Corona de Aragón. De nuevo, imitar para superar.

El panteón como espectáculo. Impresionar al espectador. He aquí una de las lecturas prioritarias de la obra promovida por Pedro IV. Y no sólo aquélla de Poblet. Es bien conocido que buena parte de las manifestaciones públicas de este monarca tuvieron un marcado carácter retórico y propagandístico bajo el explícito deseo de hacer patente ante sus súbditos toda la gloria del poder real. Desde los sermones de corte hasta la liturgia de las ordinacions de la Casa Real o de la coronación se fundamentaron en una cuidada y espectacular presentación del monarca capaz de impresionar a los auditorios. El diseño del panteón se enmarca dentro de estas mismas premisas. Con sus dos grandes arcadas dispuestas a ambos lados del crucero; con las tumbas, algunas de ellas dobles, colocadas en alto y las figuras de los yacentes enfocadas hacia los espectadores; con unos sepulcros brillantes gracias a la policromía de los materiales; con unos esbeltos baldaquinos pintados de azul y oro y, por último, con una amplia y no menos vistosa colección de cimeras, escudos y epitafios repartidos por doquier, el panteón de Poblet se nos antoja un extraordinario espectáculo visual ante el que sería imposible mostrarse indiferente. ¿Pero un espectáculo para qué? ¿Y para quién o quiénes? A estas alturas no sorprenderá si afirmo que la exaltación de

42 “L'ensemble funérarire, dés lors, n'est pas seulement devenu monument, il s'impose comme spectacle, il donne à voir et non pas seulement à se souvenir": X. DECTOT, op. cit., 2009, p. 245. 
la memoria dinástica es la principal respuesta a la primera pregunta. Ni tampoco si consideramos que la segunda cuestión debe conducirnos más allá de los muros del monasterio. Y es que, aún apreciando mucho el valor salvífico de las oraciones de los monjes, no parece que Pedro IV se hubiese tomado tantas molestias a la hora de construir el conjunto funerario si su contemplación hubiera quedado reservada únicamente a los ojos de tan venerables hombres.

Que el panteón de Poblet fue concebido como un gran teatro visual de la memoria nos lo confirma la fundación de una biblioteca real en el mismo monasterio. Este proyecto ya fue esbozado en los años 50 mediante unos primeros legados de libros procedentes de la biblioteca personal del monarca. Sin embargo su materialización definitiva tuvo lugar en 1380, momento en el que se constata una nueva donación de manuscritos reales y la fundación efectiva de una biblioteca que hiciese posible la conservación conjunta de todos ellos ${ }^{43}$. Significativamente entre las obras reunidas destacaban "specialiter libris historiarum regum Aragonum ac comitatum Barchinone", a los que también se añadió una colección de crónicas y libros de historia de otros reinos, algunos próximos, otros remotos. Lo interesante en cualquier caso es que el gesto dio carta de naturaleza a algo más que un simple depósito de la memoria dinástica o a un mero acopio de crónicas y genealogías. Para ello sólo hace falta leer el propio documento de fundación, en el que se señala de manera explícita que los libros fueron donados, básicamente, como un complemento ideal del panteón dinástico. En puridad, para que los monjes, después de los oficios, y los nobles visitantes del monasterio, al leer los epitafios de los reyes sepultados en el monasterio, no tuvieran que preguntar cuáles habían sido sus magníficas gestas y de qué manera habían aumentado valerosamente un reino tan pequeño en sus inicios ${ }^{44}$. El objetivo declarado de la biblioteca era, pues, informar e instruir a los habitantes y visitantes del monasterio; ofrecerles la información necesaria para que, al contemplar el grandioso panteón, al leer los epitafios adjuntos a los sepulcros, dispusieran de los argumentos necesarios que les permitieran celebrar las gestas de los reyes allí enterrados. En resumen, para que quienes admirasen el monumental conjunto funerario se convirtieran no tan sólo en testimonios sino también en apologetas de una grandiosa historia dinástica. Libros para guiar la mirada y fundamentar la memoria. Leer para ver.

A partir de estas premisas se entiende que los códices no se encerraran en un oscuro archivo o en grandes cofres. Si el deseo era hacer de ellos un instrumento de uso e interpretación del panteón al alcance de los monjes pero también de un pú-

43 J. RUBIÓ I BALAGUER, "La institució de la biblioteca reial a Poblet en temps de Pere el Cerimoniós", Història i Historiografia, Barcelona-Abadia de Montserrat, 1987, pp. 411-453. Anotaciones críticas en F.M. GIMENO BLAY, op. cit., 2006, pp. 178-194.

44 “...ut vos, post factum divinum obsequium, nobilisque persone que ad dictum monasterium sepe confluunt, habeatis unde legendo, delectemini ac etiam discatis proficiscamini quod si ea que bene acta legeretis imitari, male autem vitare velitis immo quod quasi necessarium nobis videtur ut qui epigrammata legent tumulorum et illourum predecessorum nostrorum quorum cineres in dicta ecclesia vestra quiscunt, non longe inquirere habeant quam magnifica ipsi alii predecessores nostri fecerunt et quomodo semper eorum imperium, quod ab exordio valde mininum fuit, virtuose creverint, ita quod merito appellari possint semper augusti, quorum celebri gesta, si a subtilibus ingeniis decorata fuissent (...), universum orbem pro maximus haberentur...". J. RUBIÓ I BALAGUER, op. cit., 1987, p. 447. 
blico más amplio llegado de allende los muros del monasterio, es evidente que se tenían que guardar en un espacio que facilitase su consulta. De ahí la fundación de una biblioteca abierta -entiéndase el término en su restrictiva acepción medieval- a todos aquellos visitantes que, necesariamente cultos y elitistas, se interesasen por el conjunto funerario y su significado. Fue con este objetivo que en 1381 el rey ordenó construir una sala con cubierta de piedra en la que se pudieran consultar los libros, eso sí, cuidadosamente encadenados en unos bancos decorados con el escudo real. Una biblioteca que, pese a que probablemente nunca se acabó construyendo, sirviera para asegurar la conservación y la lectura de los libros; que facilitase el acceso, no sólo de los monjes sino también de los laicos, a unos textos pensados para comprender y practicar la celebración dinástica materializada en piedra en el gran monumento funerario ${ }^{45}$. Todo para completar el espectáculo del panteón y su capacidad retórica. Y para que no hubiera ninguna duda de quién había sido el factotum de todo ello, se ordenó gravar la inscripción "Llibreria del rei Pere III d'Aragó" 46 sobre la puerta de entrada a la sala. Memoria del linaje, sí; exaltación personal de Pedro IV, también.

La voluntad de facilitar la comprensión de la retórica funeraria expresada en el panteón acabó también por determinar el sentido y función de otros productos literarios y visuales realizados para el cenobio tarraconense. Destaquemos, entre ellos, el manuscrito del Llibre dels Feits de Jaime I encargado por el abad Ponç de Copons (1343) o el llamado Rollo de Poblet, una pieza seguramente pensada para su exhibición ritual realizada en torno a 1409-10 por deseo del rey Martín el Humano ${ }^{47}$, hijo de Pedro IV y entusiasta continuador de la obra paterna. A pesar de haber sido realizadas, respectivamente, antes y después del panteón funerario, cabe reconocer que ambas obras ofrecen una especial vinculación con el conjunto escultórico. Así debieron interpretarlo los espectadores coetáneos, para quienes el gran monumento escultórico debió constituir el vértice y punto de confluencia de todas las obras de glorificación dinástica presentes en el monasterio. Al mismo tiempo dichos productos nos recuerdan que el proyecto auspiciado e inspirado por el monarca acabó materializándose gracias a las colaboraciones y aportaciones de un buen número de personajes, algunos de su entorno, otros posteriores a él. Es el caso del abad Copons y del rey Martín. Pero también de individuos como Guillem Nicolau, autor de los epitafios de los sepulcros -amén de traductor de varias crónicas- y de Bernat Miquel, secretario de la cancillería real y redactor del pomposo documento de fundación de la Biblioteca real. Una circunstancia que pone de manifiesto hasta qué punto la cancillería -o sea la corte- también participó activamente en la construcción del monumento populetano.

Al final del reinado de Pedro IV el conjunto funerario estaba prácticamente concluido. Los dos grandes arcos con sus múltiples sepulcros y su suntuosa decoración acogían los restos de los numerosos difuntos -antecesores y coetáneos al rey- y además estaban preparados para recibir los monumentos funerarios de los futuros monarcas. Pero más allá de todo ello lo verdaderamente interesante es que por aquel

45 Ibidem, pp. 439-443.

46 El numeral corresponde a su intitulación como conde de Barcelona.

47 A. SERRA, "La historia de la dinastía en imágenes: Martín el Humano y el rollo genealógico de la Corona de Aragón", Locus Amoenus, 6 (2002-2003), pp. 57-74. 
entonces también se habían sentado las bases de un nuevo y retórico espacio multimedia para la celebración de la dinastía aragonesa. Un monumento, en definitiva, "construido" a partir de la interacción de diferentes medios de comunicación, en el que la contemplación ideal de los sepulcros se planteaba tras la lectura de las gestas de los personajes enterrados contenidas en los libros de la biblioteca real. Un espacio que, recordémoslo, Pedro IV también prescribió que fuera el escenario final de las exequias regias, la última parada de la liturgia funeraria oficiada tras la recepción de los cuerpos de los monarcas en el monasterio y el ritual de "córrer les armes" desplegado en diferentes ámbitos del mismo. Unas ceremonias dramáticas, espectaculares, cargadas de simbolismo: pro remedio anima pero también ad maiorem gloriam del monarca difunto y del linaje al que pertenecía. En definitiva, hacía 1387, fecha de la muerte de Pedro IV, en Poblet se había completado la definición de un vasto espacio de intersecciones comunicativas en favor del recuerdo de la dinastía, cuyo epicentro era el gran panteón y su compleja composición a base de imágenes, símbolos y textos. De modo semejante a lo sucedido en el Salón del Tinell del Palacio Real Mayor de Barcelona, se había alumbrado una apoteosis visual de la memoria para que el rey y su dinastía vivieran para siempre. 